\title{
Identification of a Growth Hormone-Responsive STAT5- Binding Element in the Rat Insulin 1 Gene
}

\author{
Elisabeth D. Galsgaard ${ }^{\star}$, Fabrice Gouilleux, Bernd Groner, \\ Palle Serupt, Jens H. Nielsen, and Nils Billestrup \\ Hagedorn Research Institute (E.D.G., P.S., J.H.N., N.B.) \\ DK-2820 Gentofte, Denmark \\ Institute for Experimental Cancer Research (F.G., B.G.) \\ Tumor Biology Center \\ D-79106 Freiburg im Breisgau, Germany
}

GH and PRL stimulate both proliferation and insulin production in pancreatic $\beta$-cells as well as in the rat insulinoma cell line $\mathrm{RIN}-5 \mathrm{AH}$. We report here that human $\mathrm{GH}$ increases insulin mRNA levels in RIN-5AH cells via both somatogenic and lactogenic receptors. GH stimulated the rat insulin 1 promoter activity 2-fold, and this stimulation was abolished by introduction of a block mutation in a $\gamma$-interferon-activated sequence (GAS)-like element (GLE) with the sequence 5'-TTCTGGGAA-3' located in the rat insulin 1 enhancer at position -330 to -322 . This element, termed Ins-GLE, was able to confer $\mathrm{GH}$ responsiveness to a heterologous promoter. GH induced the binding of two protein complexes to the Ins-GLE. An antibody directed against the transcription factor STAT5 (signal transducer and activator of transcription) supershifted the $\mathrm{GH}$-induced complexes. Furthermore, in COS7 cells transiently transfected with STAT5 and GH receptor cDNAs, it was found that expression of STAT5 was necessary for GH induction of these two DNA-binding complexes. These results suggest that $\mathrm{GH}$ stimulates insulin 1 promoter activity by inducing the binding of STAT5 to Ins-GLE. (Molecular Endocrinology 10: 652-660, 1996)

\section{INTRODUCTION}

$\mathrm{GH}$ and the related hormones PRL and placental lactogen $(\mathrm{PL})$ have been shown to stimulate proliferation of rat pancreatic $\beta$-cells and the rat insulinoma-derived cell IIne RIN-bAH (1, 2). Furthermore, these hormones are also able to stimulate insulin biosynthesis in both these cell types $(1,2)$. The RIN 5 AH cells express both $\mathrm{GH}$ and $\mathrm{PR} L$ receptors (GHR and $P R L R$ ) (3), and

$0888-8809 / 96 / \$ 3.00 / 0$

Molecular Endocrinology

Copyright $(9) 1996$ by The Endocrine Society the cloned GHR has been found to be capable of mediating the insulinotrophic effect of $\mathrm{GH}(4)$. We have previously reported that human (h) $\mathrm{GH}$ increases the steady state level of insulin mRNA in the RIN-5AH cells (5) and that human $\mathrm{GH}(\mathrm{hGH})$ stimulates endogenous insulin gene expression in these cells (6). Despite an extensive characterization of cis-acting elements in the insulin enhancer, no evidence for a specific $\mathrm{GH}$ responsive element has so far been recognized (7). Thus the mechanisms involved in $\mathrm{GH}$-stimulated insulin gene transcription have not been defined

The effects of $\mathrm{GH}$ are mediated by specific GHRs that belong to the cytokine receptor superfamily (8). Although activation of receptors of this family induces intracellular tyrosyl phosphorylation, they are characterized by the lack of intrinsic tyrosine kinase activity. Mounting evidence demonstrates that many of these receptors activate tyrosine kinases of the Janus kinase (JAK) family (9). These kinases were first identified to be involved in the signal transduction pathway used by interferon- $\alpha$ and $-\gamma$, now known as the JAK-STAT (signal transducer and activator of transcription) pathway (10). One of the four currently known members of the JAK family, JAK2, has been shown to be activated by $\mathrm{GH}$ (11). Upon $\mathrm{GH}$-induced dimerization of the GHR (12), JAK2 is recruited to the receptor, which leads to autophosphorylation of JAK2 and phosphorylation of the GHR (11). Other proteins have been shown to be tyrosyl phosphorylated in response to $\mathrm{GH}$, including STAT-1, -3 , and $-5(13-15)$. STAT proteins are latent, cytoplasmic transcription factors that upon phosphorylation will dimerize and translocate to the nucleus where the STAT proteins bind $\gamma$-interferon activated sequences (GAS)-like elements (GLEs) and activate transcription of target genes (10). STAT1 and STAT3 have been shown to bind as homo- and heterodimers to a regulatory element in the c-fos gene termed SIE (sis-inducible element) and have been implicated in the $\mathrm{GH}$-induced up-regulation of c-fos gene transcription (13, 14). STAT5/MGF (mammary gland factor) was 
first found to be involved in the PRL-induced activation of $\beta$-casein gene expression (16). Recently STAT5 has been suggested to be involved in the $\mathrm{GH}$-induced up-regulation of the liver-specific serine protease inhibitor 2.1 (SPI 2.1) gene transcription, since STAT5 was found to be part of a $\mathrm{GH}$-induced protein complex binding to the GLE1 of the GH-responsive element II (GHRE II) present in the SPI 2.1 promoter/enhancer region (17).

In this report we have examined the promoter/enhancer region of the insulin gene to identify putative GHRE(s). Furthermore, we have characterized the involvement of STAT5 in this $\mathrm{GH}$-induced up-regulation of insulin promoter activity.

\section{RESULTS}

\section{GH-Induced Insulin mRNA Expression in RIN-5AH Cells}

To examine the effect of hGH on insulin mRNA levels, RIN-5AH cells were stimulated with hGH for 1-4 days and Northern blot analysis was performed. Human $\mathrm{GH}$ was found to increase insulin mRNA level time-dependently with an approximately 4-fold induction after 3-4 days. In contrast, the level of cyclophilin mRNA was unaffected by hGH when equal amounts of total RNA were analyzed (Fig. 1A). The effect of hGH was dosedependent with maximal insulin mRNA levels observed at $500 \mathrm{ng} / \mathrm{ml} \mathrm{hGH} \mathrm{(Fig.} \mathrm{1B).}$

In rat cells, hGH is known to bind both the GHR and the PRLR. Therefore, RIN-5AH cells were stimulated with hormones with either somatogenic [rat (r) GH or bovine (b) $\mathrm{GH}$ )] or lactogenic [rPRL, ovine (o) PRL, or human placental lactogen (hPL)] specificity. Northern blot analysis showed that both types of hormones were able to mediate the insulinotrophic effect of hGH (Fig. 2).

\section{GH-Stimulated Rat Insulin 1 Promoter Activity}

To determine whether the $\mathrm{GH}$-induced increase in insulin mRNA levels was due to an increase in the activity of the insulin promoter, RIN-5AH cells were transiently transfected with the plasmid rins1(wt)-CAT, which contains the rat insulin 1 promoter/enhancer region from -345 to +1 placed in front of the reporter gene chloramphenicol acetyl transferase (CAT). Stimulation of the transfected cells with hGH increased the CAT activity 1.9-fold. In contrast, the level of CAT activity in cells transfected with a reporter plasmid containing the minimal thymidine kinase promoter (TK-CAT) was not increased by hGH stimulation (1.1-fold induction by GH, Fig. 3B), indicating a specific effect of hGH on the insulin promoter.

\section{GH-Responsiveness of the Insulin Gene}

A GLE in the rat insulin 1 enhancer at position -330 to -322 was identified by sequence homology search and termed Ins-GLE (see Fig. 3A). To determine whether this region is involved in the $\mathrm{GH}$ responsiveness of the insulin gene, the plasmid rins1(S31)-CAT, in which a block mutation was introduced at position -330 to -322 of the insulin enhancer (see Fig. $3 \mathrm{~A}$ ), was analyzed by CAT assay. No significant effect of $\mathrm{hGH}$ on this construct was found when compared with
A

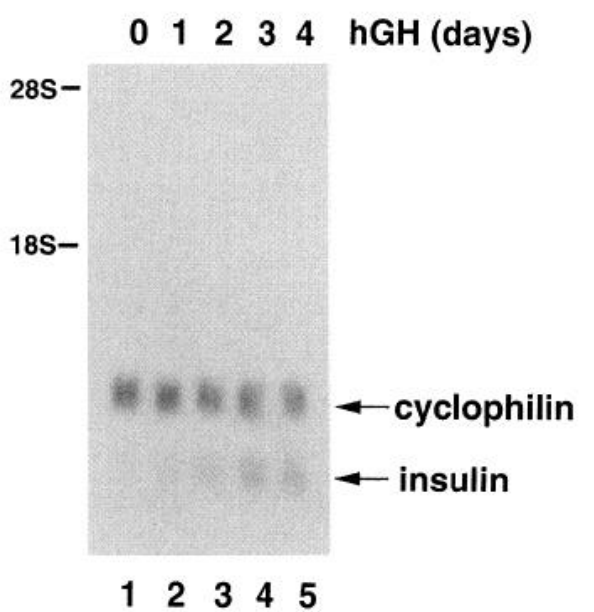

B

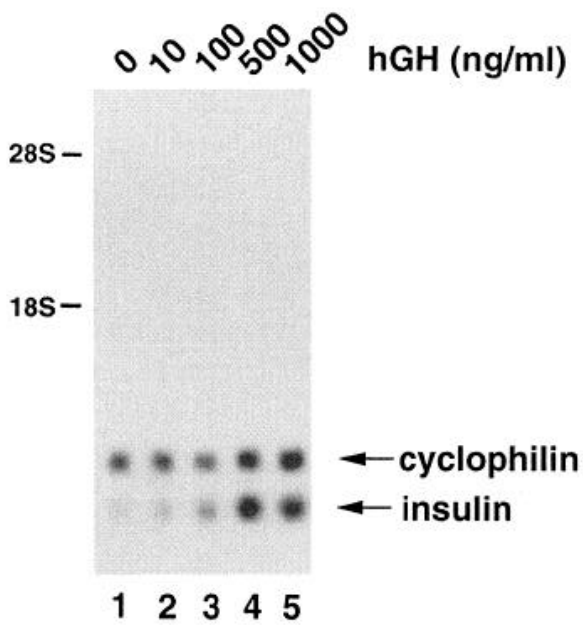

Fig. 1. Effect of hGH on Insulin mRNA Level

A, Total RNA was isolated from RIN-5AH cells stimulated with $1 \mu \mathrm{g} / \mathrm{ml} \mathrm{hGH}$ for $0,1,2,3$, and 4 days (lanes $1-5$ ). B, RIN-5AH cells were stimulated for 2 days with $0,10,100,500$, or $1000 \mathrm{ng} / \mathrm{ml} \mathrm{hGH}$ (lanes 1-5). Northern blot analysis was performed as described in Materials and Methods using radiolabeled probes specific for insulin and cyclophilin, respectively. The bands corresponding to insulin and cyclophilin mRNA are marked by the arrows, and the migration of $28 \mathrm{~S}$ and 18S ribosomal RNA is indicated. The autoradiographs shown are representative of four independent experiments. 


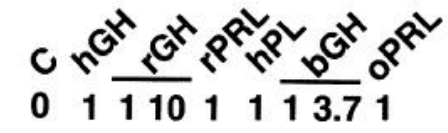

hormone

$0111011 \overline{13.7}$ conc $(\mu \mathrm{g} / \mathrm{ml})$

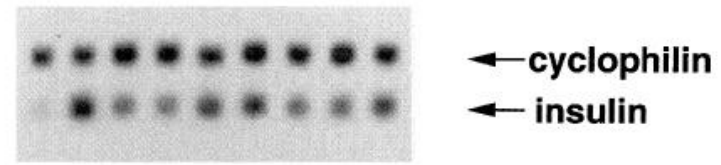

1233456789

Fig. 2. Effect of Somatogenic and Lactogenic Hormones on Insulin mRNA Level

RIN-5AH cells were stimulated with the indicated hormones for 2 days, after which total RNA was isolated and Northern blot analysis performed. The bands corresponding to insulin and cyclophilin mRNA are indicated by arrows. The autoradiograph shown is representative of three independent experiments.

the control plasmid TK-CAT (1.3-fold induction by GH, Fig. 3B).

To examine whether the GLE of the insulin gene can mediate GH responsiveness to a heterologous promoter, we made a construct in which 10 copies of the oligonucleotide Ins-GLE ( -331 to -321$)$ was inserted upstream of the TK promoter and termed this construct (Ins-GLE) $10^{-T K-C A T ~(s e e ~ F i g . ~ 3 A) . ~ W h e n ~ t e s t e d ~}$ by CAT assay, this construct showed a marked responsiveness to hGH (6.1-fold induction by $\mathrm{GH}$, Fig. 3B).

\section{GH-Induced Binding of Proteins to Ins-GLE}

We performed gel retardation experiments to examine whether GH induces the binding of proteins to InsGLE. Incubation of radiolabeled Ins-GLE oligonucleotides with nuclear extracts from RIN-5AH cells showed that hGH induces the formation of one minor and one major DNA-protein complex termed $A$ and $B$, respectively (Fig. 4A). The complexes were found to be maximally induced after $5 \mathrm{~min}$ of hGH stimulation, after which they decreased gradually (lanes 2-6). Bovine GH mimicked the effect of hGH (Fig. 4B, lane 1). In addition, two complexes with higher mobility appeared, which were not affected by GH (Fig. 4B, lanes 2-6). The two GH-induced complexes and the upper of the two constitutive complexes bound the Ins-GLE oligonucleotide specifically, since they could be competed with excess unlabeled Ins-GLE oligonucleotide (Fig. 4B, lanes 2 and 3) but not with an excess of irrelevant oligonucleotides (Fig. 4B, lanes 4 and 5).

Since Ins-GLE shows sequence homology with the SPI-GLE1 and the SIE of the c-fos gene (see Fig. 5A), we were prompted to compare the hGH-induced protein complexes that bind to these three elements. As can be seen in Fig. 5B, two hGH-induced complexes were formed with the SPI-GLE1 probe (lane 6), which have migration patterns similar to those formed with the Ins-GLE probe (lane 3). In contrast, four hGHinduced complexes were formed with the optimized
A
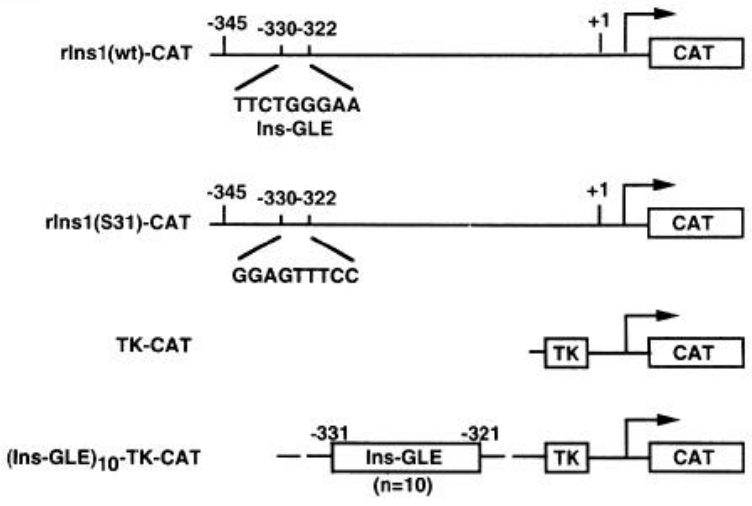

B

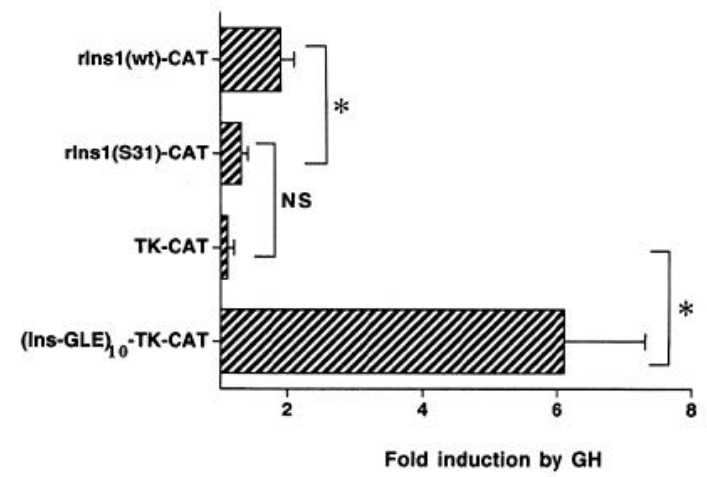

Fig. 3. Effect of hGH on Insulin Promoter Activity

A, Schematic presentation of the CAT constructs used for transient transfection of RIN-5AH cells: rlns1(wt)-CAT, rins1(S31)-CAT, TK-CAT, and (Ins-GLE) ${ }_{10}$-TK-CAT. B, RIN$5 \mathrm{AH}$ cells were transiently transfected with the CAT constructs shown in panel $A$ and cultured for 2 days in the absence or presence of hGH $(400 \mathrm{ng} / \mathrm{ml})$. Cell extracts were normalized for transfection efficiency and assayed for CAT activity. For each CAT construct tested the result is expressed in terms of fold induction by $\mathrm{GH}$. Each column represents the mean \pm SEM of four to eight independent experiments. ${ }^{*}, P<0.05$ using a Mann-Whitney $U$ test. NS, Not significant $(P>0.05)$.

SIE probe (m67) (lane 9). Three of these complexes (indicated by arrows, Fig. 6A, lanes 14-16) have previously been described to consist of STAT3 homodimers (upper band), STAT1/STAT3 heterodimers (middle band), and STAT1 homodimers (lower band) $(13,14)$. In addition, a GH-induced complex appeared with the $\mathrm{m} 67$ probe, which has the same mobility as complex A formed with the Ins-GLE probe (Fig. 5B, lane 9; and Fig. 6A, lanes 14-16).

\section{Identification of STAT5 in the Major GH-Induced Protein Complex Binding the Ins-GLE}

The presence of STAT proteins in the hGH-induced protein complexes binding to the Ins-GLE was investigated by the use of antibodies recognizing STAT1, STAT3, or STAT5. Preincubation of nuclear extract 
A

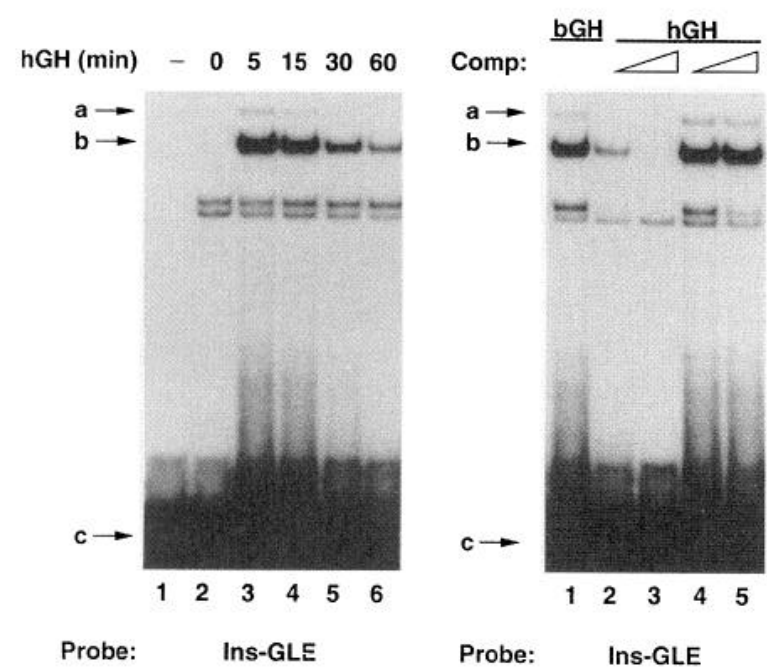

Fig. 4. hGH-Induced Protein Complexes Binding to the Insulin Gene

Gel retardation experiments were performed as described in Materials and Methods using radiolabeled Ins-GLE oligonucleotide as probe. A, Probe was incubated with $10 \mu \mathrm{g}$ nuclear extract prepared from either unstimulated RIN-5AH cells (lane 2) or cells stimulated with hGH $(400 \mathrm{ng} / \mathrm{ml})$ for 5 , 15,30 , or 60 min (lanes 3-6). B, Probe was incubated with nuclear extract from RIN-5AH cells stimulated with bGH (1 $\mu \mathrm{g} / \mathrm{ml}$ ) for $5 \mathrm{~min}$ (lane 7). Using nuclear extract from 5-min hGH-stimulated RIN-5AH cells, unlabeled Ins-GLE oligonucleotide was included in thia binding reactions at 10 -fold and 100-fold molar excess (lanes 8-9), whereas in lanes 10 and 11 nonspecific competitor $\alpha \mathrm{CG}$ oligonucleotide was included at 10 -fold and 100 -fold molar excess, respectively. Arrows a and $b$ indicate the migration of the two $\mathrm{GH}$-induced DNAprotein complexes, whereas arrow $c$ indicates the free probe. The autoradiograph shown is representative of three independent experiments.

with $\alpha$ STAT5 antiserum resulted in a dose-dependent decrease in intensity of complex B (Fig. 6A, lanes 7-9), whereas preimmune serum (lanes 4-6), $\alpha$ STAT1 antibody (lane 10), and $\alpha$ STAT3 antibody (lane 11) did not significantly alter the intensity of complex B. Prolonged exposure of the gel showed that complex $A$ was affected neither by $\alpha$ STAT1 nor $\alpha$ STAT3 antibodies. However, it was not possible from this experiment to determine the effect of $\alpha$ STAT5 antiserum on complex $A$ due to the supershift of complex $B$ to the same position as complex A. The specific, but non-GHinducible, complex was not recognized by the $\alpha$ STAT1, -3 , or -5 antibodies (data not shown). The ability of the $\alpha$ STAT 1 and $\alpha$ STAT3 antibodies to recognize STAT1- and STAT3-containing DNA-protein complexes, respectively, was tested by the use of the m67 probe (Fig. 6A, lanes 12-16). In agreement with the findings of others (see above) the $\alpha$ STAT1 antibody supershifted the two lower $\mathrm{GH}$-induced complexes (lane 15), whereas the $\alpha$ STAT3 antibody supershifted the two upper $\mathrm{GH}$-induced complexes (lane 16).

\section{A Ins-GLE TTCTGGGAA SPI-GLE1 TTCTGAGAA SIE (c-fos) TTCCCGTCA m67 TTCCCGTAA}

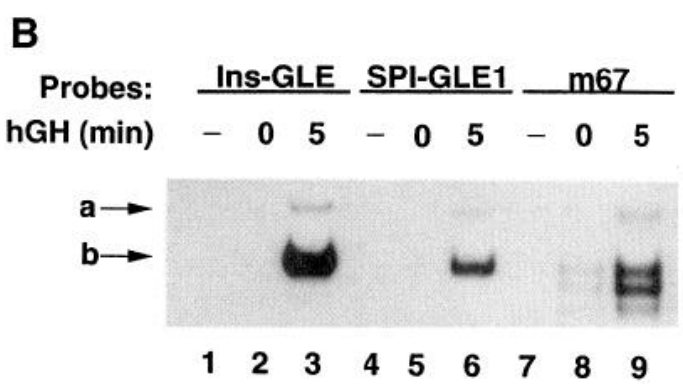

Fig. 5. Comparison of the hGH-Induced Protein Complexes Binding to the Insulin, SPI, and c-fos Genes

A, Sequence alignment of four GHREs: Ins-GLE, SPIGLE1, SIE(c-fos), and m67 (optimized SIE). B, Gel retardation experiments were performed as described in Materials and Methods using the following radiolabeled oligonucleotides as probes: Ins-GLE (lanes 1-3), SPI-GLE1 (lanes 4-6), and m67 (lanes 7-9). The probes were incubated without (lanes 1, 4, and 7) or with nuclear extracts from either unstimulated RIN$5 \mathrm{AH}$ cells (lanes 2,5 , and 8 ) or cells stimulated with hGH (400 $\mathrm{ng} / \mathrm{ml}$ ) for $5 \mathrm{~min}$ (lanes 3, 6, and 9). Arrows $a$ and $b$ indicate the migration of the $\mathrm{GH}$-induced complexes formed with the Ins-GLE probe.

To obtain more direct evidence for the presence of STAT5 in complexes A and B, we transiently transfected $\operatorname{COS} 7$ cells with GHR cDNA and/or STAT5 cDNA and prepared nuclear extracts from these cells. Gel retardation experiments were carried out with radiolabeled Ins-GLE oligonucleotide. As shown in Fig. $6 \mathrm{~B}$, lane $8, \mathrm{hGH}$ increased the presence of complex B in nuclear extracts from cells transfected with both GHR cDNA and STAT5 cDNA. Prolonged exposure of the gel revealed that complex $A$ was also induced by $\mathrm{GH}$ in these cells. The two $\mathrm{GH}$-inducible complexes showed similar mobility as those found in RIN-5AH cells (Fig. 6B, lane 9). In contrast, the specific nonGH-inducible complex seen in RIN-5AH cells was absent in COS7 cells even after transfection with STAT5 cDNA. STAT5 antiserum, but not preimmune serum, was able to supershift complex B from the STAT5transfected COS7 cells (Fig. 6B, lanes 11 and 10, respectively). Again, the appearance of supershifted bands hindered determination of the presence of STAT5 in complex A. Complex B was found to be present in nuclear extracts from COS7 cells transfected with only STAT5 cDNA, and GH increased to some extent the level of this complex (Fig. 6B, lanes 3 and 4) indicating a low level of expression of endogenous GHRs in these cells. The failure to detect complex $A$ and $B$ in nuclear extracts from mock (Fig. 6B, lanes 1 and 2) and GHR cDNA-transfected cells (Fig. $6 \mathrm{~B}$, lanes 5 and 6 ), even after prolonged exposure, suggests low endogenous expression of STAT5 in cos7 cells. 
A

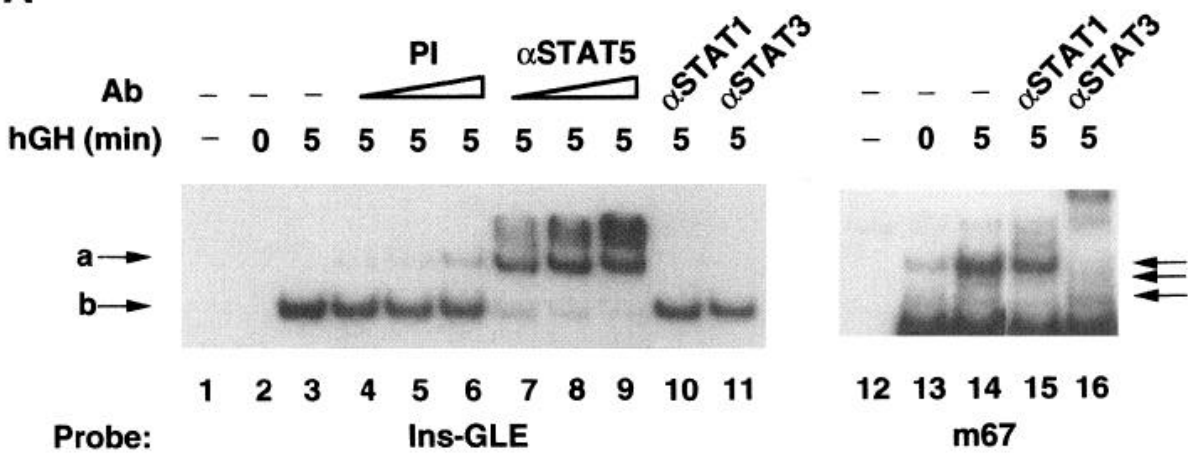

B

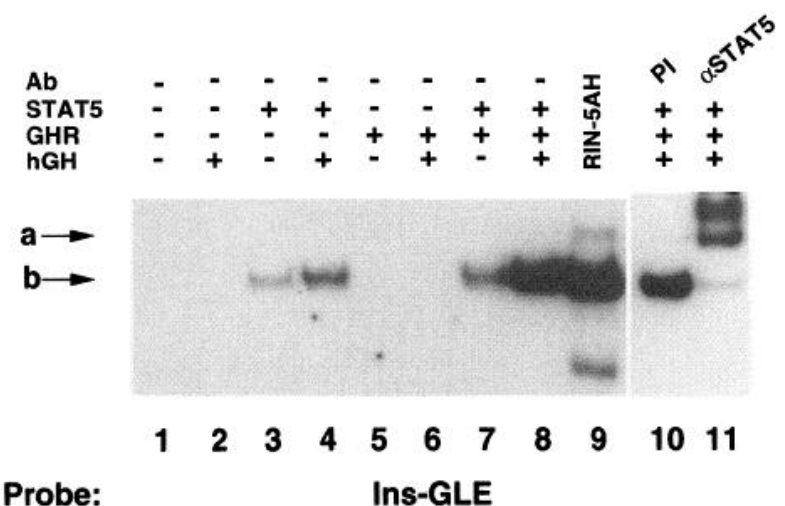

Fig. 6. The Presence of STAT Proteins in the hGH-Induced Protein Complexes Binding to the Insulin Gene

A, Nuclear extracts from either unstimulated RIN-5AH cells (lane 2) or RIN-5AH cells stimulated with hGH (400 ng/ml) for $5 \mathrm{~min}$ (lanes 3-11 and 14-16) were incubated with radiolabeled Ins-GLE or m67 oligonucleotide (lanes 1-11 and 12-16, respectively). Preincubation was performed with 1, 2, or $4 \mu \mathrm{l}$ of preimmune serum or $\alpha$ STAT5 antiserum (lanes 4-6 and 7-9, respectively). Alternatively, nuclear extracts were preincubated with $1 \mu \mathrm{l} \alpha \mathrm{STAT} 1$ (lanes 10 and 15) or $\alpha$ STAT3 (lanes 11 and 16) antibodies. The three arrows in the right part of the figure indicate the migration of the previously described SIE-binding complexes. B, Nuclear extracts from COS7 cells (lanes 1-8 and 10-11) or RIN-5AH cells (lane 9) were incubated with radiolabeled Ins-GLE oligonucleotide. COS7 cells were mock transfected (lanes 1 and 2) or transfected with pXM-MGF (STAT 5; lanes 3 and 4), pLM108 (GHR; lanes 5 and 6), or with both pXM-MGF and pLM108 (lanes 7, 8, 10, and 11). The cells were unstimulated (lanes 1, 3, 5, and 7) or stimulated with hGH $(400 \mathrm{ng} / \mathrm{ml}$ ) for 5 min (lanes $2,4,6,8-11)$. In lanes 10 and 11 the nuclear extracts were preincubated with $1 \mu \mathrm{l}$ preimmune serum or $\alpha$ STAT5 antiserum, respectively. Gel electrophoresis was performed as described in Materials and Methods. Arrows $a$ and $b$ indicate the migration of the two $\mathrm{GH}$-induced complexes.

\section{DISCUSSION}

The time- and dose-dependent increase in GH-mediated insulin mRNA steady state levels and the upregulation of the rat insulin 1 promoter activity shown here in RIN-5AH cells correlate well with the previously reported $\mathrm{GH}$-induced increase in insulin biosynthesis (2) and insulin gene transcription (6). In agreement with previous reports $(1,18)$, we found that both $\mathrm{GH}$ and $\mathrm{PRL}$ are able to stimulate insulin production. Since the maximal increase in insulin mRNA level was found to be somewhat higher than the relatively weak induction of insulin promoter activity and furthermore was reached after several days of stimulation, $\mathrm{GH}$ might also regulate the insulin mRNA level posttranscriptionally by prolonging the half-life of insulin mRNA. One of the mechanisms by which glucose has been reported to increase insulin expression is by mRNA stabilization (19), indicating that insulin mRNA half-life can be modulated by changes in the extracellular environment. The apparent discrepancy between the rapid $\mathrm{GH}$-induced binding of STAT5 to the Ins-GLE and the slow GH-induced increase in insulin mRNA may have several explanations. Since by Northern blot analysis we measure the total insulin mRNA content and since basal insulin mRNA content is high and has a long half-life, a modest increase in insulin gene transcription would be expected to yield a slow increase in total mRNA. Alternatively, it is possible that the insulin promoters response to $\mathrm{GH}$ is biphasic. In Nb2 cells, PRL has been shown to activate transcription of the IRF-1 gene in a biphasic manner with an initial transient transcriptional activation after 30-60 min followed by a more sustained stimulation after $10-12 \mathrm{~h}(20,21)$. The 
late response might be dependent upon factors induced during the early transcriptional response. A similar mechanism in $\mathrm{GH}$-induced insulin gene transcription could explain the difference in the kinetics of $\mathrm{GH}$-induced STAT5 activation and insulin MRNA accumulation.

in the rat insulin 1 enhancer at position -330 to --322 we have identified a GLE which we have named Ins-GLE, and this regulatory element was found to mediate $\mathrm{GH}$ responsiveness of the rat insulin 1 promoter. However, we can not exclude that there might be other GHREs in the insulin gene. A GA-rich region is present in the insulin promoter at the same position as a GH-regulated GAGA-box in the SPI gene $(-57$ to -40). The GAGA-box in the SPI gene has been found to be necessary for both basal and hormone-regulated transcription of the SPI gene (22). Mutation of the GA-rich region in the insulin gene was found to decrease transcription of an insulin promoter-CAT construct by $60 \%$ in the insulin-producing HIT cells and by $80 \%$ in cultured $\beta$-cells $(23,24)$. Furthermore, the transcription factor Pur-1, which binds specifically to this sequence, has been reported to be a potent transactivator of the insulin gene (25). It has not been possible, however, to detect $\mathrm{GH}$-induccd binding of protein complexes to these two elements (22). It is presently not known whether the GA-rich region in the insulin promoter is involved in $\mathrm{GH}$-regulated transcription.

The Ins-GLE is part of a region in the insulin enhancer called E1 ( -333 to -287 ) (26). The E1 element was found to interact with nuclear proteins that are present in insulin- and glucagon-producing cell lines but not in non-islet cell lines such as HELA and BHK (26-28). Mutation of the Ins-GLE has been reported to decrease transcription of an insulin promoter-CAT construct by $40 \%$ both in HIT cells and in cultured $\beta$-cells $(23,24)$. Interestingly, we find that the Ins-GLE binds a protein complex that was present in RIN-5AH cells but absent in COS7 cells (see Fig. 6B) and in $\mathrm{CHO}$ cells (data not shown). This putative islet-specific complex did not contain STAT1, -3 , or -5 , and it was found to be independent of GH. The Ins-GLE was able to confer $\mathrm{GH}$ responsiveness to a heterologous promoter not only in RIN-5AH cells but also in the noninsulin-producing $\mathrm{CHO}$ cells (data not shown). Together these data indicate that the Ins-GLE might be involved in the cell-specific expression of the insulin gene by the binding of an islet-specific protein complex, but the mechanism by which $\mathrm{GH}$ regulates insulin gene expression via this element is not $\beta$-cell type specific.

Two GH-induced protein complexes were found to bind Ins-GLE. We have shown that a STAT5-specific antibody is able to supersh ift the complex B. Detection of STAT5 in the minor complex A was unfortunately obscured by the migration of the supershifted complex $B$ to the same position as complex A. However, the two complexes were only observed in COS7 cells transfected with STAT5 cDN^. These data suggest that $\mathrm{GH}$ induces the binding of STAT5 to the Ins-GLE.
This is in agreement with our finding that $\mathrm{GH}$ induces tyrosyl phosphorylation of STAT5 in RIN-5AH cells (data not shown) and is further supported by the recently reported identification of STAT5 as the GHinduced STAT protein binding to SPI-GLE1 (17). As shown in Fig. 5B, the migration patterns of the two GH-induced complexes binding to Ins-GLE and SPIGLE1 are very similar. Together these data indicate that the homologous elements Ins-GLE and SPI-GLE1 are functionally equivalent GHREs regulated by the same JAK-STAT pathway. In contrast, the SIE of the c-fos gene binds GH-induced complexes that are distinct from the complexes that bind Ins-GLE and SPI-GLE1. These SIE-binding complexes contain STAT1 and STAT3; therefore, the SIE element seems to be regulated by another GH-activated JAK-STAT pathway.

STAT5 was originally cloned as the PRL-regulated ovine mammary gland factor MGF (16). Recently the cloning of two murine STAT5 isoforms (STAT5a and STAT5b) was reported (29-31). The STAT5 cDNA transfected into COS7 cells in this study is the ovine homolog of the murine SIATba (30). Furthermore. the antiserum directed against ovine STAT5, which we find is able to recognize the $\mathrm{CH}$-induced complex $\mathrm{B}$ in RIN-5AH cells, seems to recognize only murine STAT5 $a$ and not murine STAT5b (30). Since complex R has the same mobility in RIN-5AH cells and transfected COS7 cells, we hypothesize that this complex comprises a STAT5a homodimer. Moreover, we find that complexees $A$ and $B$ are interdependent in the sense that complex $A$ appears whenever the level of complex $\mathrm{B}$ is high. In a recent report two similar complexes, which bound the PRL response element of the $\beta$-casein gene, were observed in COS cells transfected with STAT5 cDNA (32). The authors present evidence suggesting that whereas the complex with the lower mobility is a STAT5 dimer, the complex with the higher mobility is a STAT5 tetramer. It is thus a possibility that complex A. which binds to the Ins-GLE. might be a STAT5 letramler. Although we have shown the absence of STAT1 and STAT3 in complex A and B. we can not completely exclude the possibility that other STAT proteins are present in the two complexes. Furthermore, there may be other proteins, which are not members of the STAT family, present in the GHinduced complexes. This has been shown to be the case for the interferon $\alpha$-activated DNA-binding complex which, in addition to STAT1 and STAT2, contains a $48-\mathrm{kDa}$ protein related to interferon-regulated factor and the myb families of DNA-binding proteins (33). In this respect it is interesting that $\mathrm{GH}$-regulated oscillations in intracellular free $\mathrm{Ca}^{2}$ concentration were found to be required for $\mathrm{GH}$-induced insulin gene transcription. Furthermore, a specific domain in the GHR was found to be required for activation of both the $\mathrm{Ca}^{2}$ : pathway and the $\mathrm{GH}$-induced activation of a SPI-GLE1 reporter construct (6). Thus the JAK2/ STAT5 and $\mathrm{Ca}^{2}$ pathways appear to cooperate in $\mathrm{GH}$-regulated transcription of the SPI and insulin 
genes. We are currently investigating whether the $\mathrm{GH}$ regulated $\mathrm{Ca}^{2+}$ pathway also signals via Ins-GLE and SPI-GLE1.

\section{MATERIALS AND METHODS}

\section{Cells, Hormones, and Plasmids}

RIN-5AH cells were cultured in RPMI 1640 supplemented with $10 \%$ heat-inactivated $\Gamma \mathrm{CS}, 100 \mathrm{U} / \mathrm{ml}$ penicillin, 100 $\mu \mathrm{g} / \mathrm{ml}$ streptomycin, and $2 \mathrm{~mm}$ L-glutamine at $37 \mathrm{C}$ in a humidified atmosphere containing $5 \% \mathrm{CO}_{2}$ in air. COS7 cells were cultured in DMEM ( $4500 \mathrm{mg} / \mathrm{liter}$ glucose) supplemented as described above.

Recombinant hGH was obtained from Novo Nordisk (Gentofte, Denmark); bGH and ovine PRL were from UCB-Bioproducts (Brussels, Belgium); rGH, rPRL, and human placental lactogen were gifts from National Hormone and Pituitary Program (NIDDK, University of Maryland School of Medicine, Baltimore, MD).

The insulin reporter plasmid $\mathrm{r} \mid \mathrm{ns} 1$ (wt)-CAT contains the rat insulin 1 promoter/enhancer region from -345 to +1 placed in front of the reporter gene CAT. In the mutated insulin reporter plasmid rins1(S31)-CAT (kindly provided by Dr. T. Edlund, University of Umeå, Sweden) a block mutation was introduced at position -330 to -322 (23). To generate the plasmid (Ins-GLE) ${ }_{10}$-TK-CAT, the double-stranded oligonucleotide Ins-GLE (5'-agctTTTCTGGGAAA-3') was concatenated and ligated into the vector TK-CAT (34), which contains the minimal thymidine kinase promoter and the CAT gene. The plasmid RSV-LUC was generated by insertion of Rous sarcoma virus long terminal repeat (RSV LTR) into the luciferase plasmid pGL2-basic (Promega, Madison, WI). The expression plasmids PXM-MGF (15) and pLM108 (14) contain the coding regions of OMGF/STAT5 and rGHR, respectively.

\section{Northern Blot Analysis}

RIN-5AH cells $\left(1-2 \times 10^{6}\right)$ were cultured in $100-\mathrm{mm}$ tissue culture dishes for $1-2$ days in RPMI 1640 containing 10\% FCS. The medium was changed to RPMI 1640 containing $0.5 \% \mathrm{FCS}$, and the cells were cultured in the presence or absence of hormone for the indicated time. Total RNA was extracted from RIN-5AH cells using the single step acidguanidium-thiocyanate-phenol-chloroform method (35). RNazol (Cinna/Biotecx Laboratories International Inc., Houston, TX) was added directly to the culture dishes, and RNA was isolated according to the manufacturer's instructions. Twenty micrograms of total RNA were separated by denaturing agarose gel electrophoresis in the presence of ethidium bromide to use $18 \mathrm{~S}$ and $28 \mathrm{~S}$ ribosomal RNA as molecular weight markers. The RNA was blotted onto nitrocellulose and immobilized by baking. The filter was prehybridized at $42 \mathrm{C}$ in the presence of $50 \%$ formamide, $5 \times$ sodium chloride-sodium citrate, $5 \times$ Denhardts, $0.1 \%$ SDS, $20 \mathrm{mM} \mathrm{Na}_{2} \mathrm{PO}_{4}, \mathrm{pH} 6.5$, and $0.2 \mathrm{mg} / \mathrm{ml}$ sonicated herring sperm DNA and hybridized at $42 \mathrm{C}$ in the presence of $50 \%$ formamide, $5 \times$ sodium chloride-sodium citrate, $1 \times$ Denhardts, $0.1 \%$ SDS, $20 \mathrm{~mm} \mathrm{Na} \mathrm{PO}_{1}, \mathrm{pH} 6.5,0.2 \mathrm{mg} / \mathrm{ml}$ sonicated herring sperm DNA, and approximately $10^{6} \mathrm{cpm} / \mathrm{ml}$ of each of the following two cDNA probes which were ${ }^{32} \mathrm{P}$-labeled using a random primer labeling kit (Amersham, Buckinghamshire, England): a 500-bp cDNA Pstl-fragment from the rat insulin gene (kindly provided by William Kastern) and a 477-bp cDNA Alul-fragment from the rat cyclophilin gene (36). The filter was washed and examined by autoradiography. The relative amounts of insulin and cyclophilin RNA were quantitated using a Biolmage Densitometric Scanning Program (Millipore, Bedford, MA)

\section{Transient Transfections}

RIN-5AH cells $\left(2-3 \times 10^{6}\right)$ were transfected in $100-\mathrm{mm}$ tissue culture dishes using the calcium-phosphate method essentially as described (37) with $15 \mu \mathrm{g}$ CAT reporter plasmid and $5 \mu \mathrm{g}$ RSV-LUC plasmid per dish. Transfected cells were cultured for 2 days in RPMl 1640 containing 2\% FCS in the presence or absence of $400 \mathrm{ng} / \mathrm{ml} \mathrm{hGH}$, after which CAT assay was performed (see below).

COS7 cells $\left(2 \times 10^{6}\right)$ were transiently transfected in $100-\mathrm{mm}$ tissue culture dishes by the DEAE-dextran method essentially as described (37) using a total of $10 \mu \mathrm{g}$ plasmid DNA per dish. Cells were either mock transfected with carrier DNA or transfected with pXM-MGF (5 $\mu \mathrm{g} /$ dish) and/or pLM108 $(0.5 \mu \mathrm{g} / \mathrm{dish})$. Cells from each dish were replated in two 100 -mm dishes $\left(1.5 \times 10^{6}\right.$ cells per dish $)$ and one six-well plate ( $2 \times 10^{5}$ cells per well) the day after transfection. The six-well plate was used for $\mathrm{GH}$-binding experiments (2) to assure that the levels of $\mathrm{GH}$ expression were comparable between the differently transfected celis. Specific $\left[{ }^{125}\right] \mathrm{hGH}$ binding was detected only in cells transfected with pLM108 (data not shown). Cells plated in 100-mm dishes were used for preparation of nuclear extracts.

\section{CAT Assay}

Transiently transfected $\mathrm{RIN}-\mathrm{bAH}$ cells were scraped oft in PBS and lysed in $100 \mu \mathrm{l}$ reporter lysis buffer (Promega). Luciferase activity in the cell extracts was measured using a luciferase assay system (Promega), and the luminescence was quantitated with a luminometer (Lumat LB 9501. Berthold, Belgium). The cell extracts, normalized to luciferase activity, were assayed for CAT activity using $\left[{ }^{44} \mathrm{C}\right]$ chloramphenicol and TLC as described (37). The levels of CAT activity were quantitated using a Phosphorlmager and the IMAGE QUANT program (Molecular Dynamics, Sunnyvale, CA). CAT conversions of $2.9 \pm 1.0 \%$ were obtained when approximately $70 \%$ of the exlracl from unstirnulated. TK-CAT-transfected RIN-5AH cells was incubated overnight. For (InsGLE) ${ }_{10}$-TK-CAT-transfected cells the CAT conversion was $7.5 \pm 1.9 \%$. Due to the very high activity of the insulin promoter in insulin-producing cells, approximately $20 \%$ of the extract from rIns1(wt)-CAT or rIns1(S31)-CAT-transfected cells was incubated for $2 \mathrm{~h}$ in order to obtain levels of CAT conversion similar to those obtained for the TK-CAT and (Ins-GLE) ${ }_{10}$-TK-CAT constructs. In the RIN-5AH cells the level of expression of the S31 mutant was similar to that of the wild type construct.

\section{Nuclear Extracts}

RIN-5AH cells $\left(1.5-2 \times 10^{6}\right)$ were cultured in tissue culture plates for 2 days in RPMI 1640 containing 10\% FCS. The medium was changed to RPMl 1640 containing $0.5 \%$ rCS and after $16 \mathrm{~h}$ the cells were incubated with or without hor mone $(400 \mathrm{ng} / \mathrm{ml} \mathrm{hGH}$ or $1 \mu \mathrm{g} / \mathrm{ml} \mathrm{bGH})$ for the indicated time. The cells were washed in PBS and scraped off in PBS supplemented with $0.5 \mathrm{mM} \mathrm{Na}_{3} \mathrm{VO}_{4}$. After centrifugation at 2500 $\times g$ for $5 \mathrm{~min}$, the cell pellets were resuspended in hypotonic buffer A (20 mm HEPES pH 7.9, $10 \mathrm{~mm} \mathrm{KCl}, 1 \mathrm{~mm} \mathrm{MgCl}_{2}, 1 \mathrm{~mm}$ EDTA, 1 mm dithiothreitol, $0.5 \mathrm{~mm}$ 4-(2-aminoethyl)-benzenesulfonyl fluoride, $1 \mathrm{~mm} \mathrm{Na}_{3} \vee \mathrm{O}_{4}, 1 \mu \mathrm{g} / \mathrm{ml}$ leupeptin, $1 \mu \mathrm{g} / \mathrm{ml}$ aprotinin, 20\% glycerol). The cells were lysed in a glass Dounce homogenizer. The nuclei were collected by centrifugation at $2500 \times g$ for $5 \mathrm{~min}$ and extracted for $30 \mathrm{~min}$ on a rocking bench in hypertonic buffer B (buffer A with $400 \mathrm{~mm}$ $\mathrm{NaCl}$ ). The extracts were centrifuged at $20,000 \times g$ for 30 $\mathrm{min}$, and aliquots of the supernatants were frozen in liquid nitrogen and stored at $-70 \mathrm{C}$.

Transiently transfected COS7 cells were cultured for $16 \mathrm{~h}$ in DMEM containing $0.5 \%$ FCS and incubated in the presence or absence of hGH $(400 \mathrm{ng} / \mathrm{ml})$ for $5 \mathrm{~min}$. The cells were 
then washed twice in PBS and lysed in buffer A containing $1 \%$ Triton. The cells were scraped of and nuclei were collected by centrifugation for $5 \mathrm{~min}$ at $2500 \times \mathrm{g}$, after which they were extracted for 30 min on a rocking bench in hypertonic buffer $B$. The extracts were centrifuged at $20,000 \times g$ for $30 \mathrm{~min}$, and aliquots of the supernatant were frozer in liquid nitrogen and stored at $-70 \mathrm{C}$. Protein concentrations were measured using Bio-Rad protein assay (Bio-Rad Laboratories. Munchen, Germany).

\section{Gel Retardation Experiments}

Three different double-stranded oligonucleotides were used as probes: Ins-GLE (see above), SPI-GLE1 (5'-agctATGTTCTGAGAAAATC-3'), and the optimized SIE from the c-fos gene (m67) (5'-agctTCATTTCCCGTAAATCCCTA-3'). The probes were ${ }^{32} \mathrm{P}$-radiolabeled in a fill-in reaction using DNA polymerase (Klenow fragment). Nuclear extracts ( $10 \mu \mathrm{g}$ protein from RIN$5 \mathrm{AH}$ and $5 \mu \mathrm{g}$ protcin from COS7) were incubated for $30 \mathrm{~min}$ at $30 \mathrm{C}$ with $20 \mathrm{fmol}$ probe in a $20-\mu l$ reaction containing $20 \mathrm{~mm}$ HEPES, pH 7.9, $50 \mathrm{~mm} \mathrm{NaCl}, 1 \mathrm{~mm} \mathrm{MgCl}$, $1 \mathrm{~mm}$ EDTA, $1 \mathrm{~mm}$ dithiothreitol, $10 \%$ glycerol, and $0.1 \mathrm{mg} / \mathrm{mil}$ polydeoxyinosinicdeoxycytidylic acid-polydeoxyinosinic-deoxycytidylic acid. Free and bound probe were separated on a $5 \%$ polyacrylamide gel containing $2 \%$ glycerol and $0.25 \times \mathrm{TBE}(25 \mathrm{~mm}$ Tris $/ \mathrm{HCl}, 25$ $\mathrm{mM}$ boric acid, $0.25 \mathrm{~mm}$ EDTA; $\mathrm{pH} 7.9$ ). The gel was dried and exposed to autoradiography. In competition studies 200 or 2000 tmol (10-fold and 100-fold molar excess, respectively) of unlabeled Ins-GLE was added to the binding reaction. Alternatively, unlabeled $" \mathrm{rGG}\left(5^{\prime}\right.$-GATCAAATTGACGTCATGGTAAAA-3') oligonucleotide was used as a nonspecific competitor. In supershift studies nuclear extracts were preincubated at $4 \mathrm{C}$ for $1 \mathrm{~h}$ with $1 \mu$ preimmune scrum, $\alpha$ STAT5 antiscrum (17), or $\alpha$ STAT1 antibody (Transduction Laboratories, Lexington, KY).

\section{Acknowledgments}

We thank Thomas Edlund for the kind gift of the rins1(wt)CAT and rins1(S31)-CAT constructs; Carina Svensson, Annette Moldrup Perregaard, and Johnny Arnsdorf Hansen for helpful discussion; Erica Nishimura for critical review of the manuscript; and Jannie Rosendahl Christensen and Tina Kisbye for excellent technical assistance.

Received October 24, 1995. Revision received February 1 , 1996. Accepted February 28, 1996.

Addross roquests for reprints to: Nils Billestrup, Niels Steensensvej 6, DK-2820 Gentofte, Denmark.

This work was supported in part by the Juvenile Diabetes Foundation International.

'Supported by the Danish Research Academy

†Supported by a grant from the Danish National Research Foundation.

\section{REFERENCES}

1. Nielsen JH 1982 Effects of growth hormone, prolactin and placental lactogen on insulin content and release. and deoxyribonucleic acid synthesis in cultured pancreatic islets. Endocrinology 110:600-606

2. Billestrup N. Martin JM 1985 Growth hormone binding to specific receptors stimulates growth and function of cloned insulin-producing rat insulinoma RIN-5AH cells. Endocrinology 116:1175-1181

3. Moldrup A, Billestrup N, Nielsen JH 1990 Rat insulinoma cells express both a 115-kDa growth hormone receptor and a 95-kDa prolactin receptor structurally related to the hepatic receptors. J Biol Chem 265:8686-8690

4. Billestrup N, Moldrup A, Serup P. Mathews IS, Norstedt $G$, Nielsen JH 1990 Introduction of exogenous growth hormone receptors augments growth hormone-responsive insulin biosynthesis in rat insulinoma cells. Proc Natl Acad Sci USA 87:7210-7214

5. Petersen ED, Billestrup N, Nielsen JH 1990 Effect of growth hormone and serum on the expression of the proto-oncogenes $\mathrm{c}$-jun and $\mathrm{c}$-fos in insulin producing cells. Biomed Biochim Acta 49:1171-1175

6. Billestrup N. Bouchelouche P. Allevato G. Ilondo $M$ Nielsen JH 1995 Growth hormone receptor C-terminal domains required for growth hormone-induced intracellular free $\mathrm{Ca}^{2}$ oscillations and gene transcription. Proc Natl Acad Sci USA 92:2725-2729

7. Philippe $\mathrm{J} 1994$ Pancreatic expression of the insulin and glucagon genes: update 1994. Endocr Rev 2:21-27

8. Bazan JF 1990 Structural design and molecular evolution of a cytokine receptor superfamily. Proc Natl Acad Sci USA 87:6934-6938

9. Ihle JN, Kerr IM 1995 Jaks and Stats in signaling by the cytokine receptor superfamily. Trends Genet 11:69-74

10. Darnell JE, Kerr IM, Stark GR 1994 Jak-STAT pathways and their transcriptional activation in response to INFS and other extracellular signaling proteins. Science 261 $1415-1421$

11. Argetsinger LS, Campbell GS, Yang $X$. Witthuhn BA. Silvennoinen O, Ihle JN, Carter-Su C 1993 Identification of JAK2 as a growth hormone receptor-associated tyrosine kinase. Cell $74: 1-8$

12. Cunningham $B C$, Ultsch $M$, de Vos $A M$, Mulkerrin $M G$. Clauser KR, Wells JA 1991 Dimerization of the extracellular domain of the human growth hormone receptor by a single hormone molecule. Science 254:821-825

13. Meyer DJ, Campbell GS, Cochran BH. Argetsinger LS. Larner AC, Finbloom DS. Carter-Su C. Schwartz J 1994 Growth hormone induces a DNA binding factor related to the interferon-stimulated 91-kDa transcription factor. J Biol Chem 269:4701-4704

14. Campbell GS, Meyer DJ. Raz R. Levy DE. Schwartz J. Carter-Su C 1995 Activation of acute phase response factor (APRF)/Stat'3 transcription factor by growth hor mone. J Biol Chem 270:3974-3979

15. Gouilleux F. Pallard C. Dusanter-Fourt I. Wakao H. Haldosen L-A, Norstedt G. Levy D, Groner B 1995 Prolactin. growth hormone, erythropoietin and granulocyte-macrophage colony stimulating factor induce MGF-Stat5 DNA binding activity. EMBO J 14:2005-2013

16. Wakao H. Gouilleux F. Groner B 1994 Mammary gland factor (MGF) is a novel member of the cytokine regulated transcription factor gene family and confers the prolactin response. EMBO J 13:2182-2191

17. Wood TJJ, Sliva D, Lobie PE. Pircher TJ. Gouilleux F. Wakao H, Gustafsson J-A, Groner B. Norstedt G. Haldosen L-A 1995 Mediation of growth hormone-dependent transcriptional activation by mammary gland factor/ Stat 5. J Biol Chem 270:9448-9453

18. Brelje TC, Allaire P. Hegre O. Sorenson RL 1989 Effect of prolactin vs. growth hormone on islet function and the importance of using homologous mammosomatotrophic hormones. Endocrinology 125:2392-2399

19. Welsh M, Nielsen DA, Mac Krell AJ. Steiner DF 1985 Control of insulin gene expression in pancreatic $\beta$-cells and in an insulin-producing cell line. RIN-5AH. II Regulation of insulin mRNA stability. J Biol Chem 260:1359013594

20. Stevens AM, Yu-Lee L 1994 Multiple prolactin-responsive elements mediate $\mathrm{G} 1$ and $S$ phase expression of the interferon regulatory factor-1 gene. Mol Endocrinol 8:345-355

21. Stevens AM, Wang Y. Sieger KA, Lu H, Yu-Lee L 1995 Biphasic transcriptional regulation of the interferon regulatory factor-1 gene by prolactin: Involvement of $\gamma$-in- 
terferon-activated sequences and stat-related proteins. Mol Endocrinol 9:513--525

22. Le Cam A, Pantescu V, Paquereau L, Legraverend C, Fauconnier G, Asins G 1994 cis-acting elements controlling transcription from rat serine protease inhibitor 2.1 gene promoter. J Biol Chem 269:21532-215.39

23. Karlsson O, Edlund T, Moss JB, Rutter WJ, Walker MD 1987 A mutational analysis of the insulin gene transcription control region: Expression in beta cells is dependent on two related sequences within the enhancer. Proc Nat1 Acad Sci USA 84:8819-8823

24. German MS. Wang J 1994 The insulin gene contains multiple transcriptional elements that respond to glucose. Mol Cell Biol 14:4067-75

25. Kennedy GC. Rutter WJ 1992 Pur-1, a zinc-finger protein that binds to purine-rich sequences, transactivates an insulin promoter in heterologous cells. Proc Natl Acad Sci USA 89:11498-11502

26. Onlsson $H$, Edlund $T 1986$ Sequence-specific interactions of nuclear factors with the insulin gene enhancer Cell 45:35-44

27. Ohlsson H. Thor S, Edlund T 1991 Novel insulin promoter- and enhancer-binding proteins that discriminate between pancreatic $\alpha$ - and $\beta$-cells. Mol Endocrinol 5:897-904

28. Kruse F, Rose SD. Swift GH, Hammer RE, MacDonald RJ 1993 An endocrine-specific element is an integral component of an exocrine-specific pancreatic enhancer. Genes Dev 7:774-786

29. Azam M, Erdjument-Bromage $H$, Kreider BL, Xia M, Quelle F. Basu R. Saris C, Tempst P, Ihle JN, Schindler C 1995 Interleukin-3 signals through multiple isoforms of Stat5. EMBO J 14:1402-1411

30. Liu X, Robinson GW, Gouilleux F, Groner B, Hennig- hausen L 1995 Cloning and expression of Stat5 and an additional homologue (Stat5b) involved in prolactin signal transduction in mouse mammary tissue. Proc Natl Acad Sci USA 92:8831-8835

31. Mui AL-F, Wakao H, O'Farrell A-M, Harada N, Miyajima A 1995 Intcrlcukin 3, granulocyte macrophage colony stimulating factor and interleukin-5 transduce signals through two STAT5 homologs. EMBO J 14:1166-1175

32. Lai C-F, Ripperger J. Morella K'K, Wang Y, Gearing DP. Horseman ND, Campos SP, Fey GH, Baumann H 1995 STAT3 and STAT5B are targets of two different signal pathways activated by hematopoietin receptors and control transcription via separate cytokine response elements. J Biol Chem 270:23254-23257

33. Veals SA, Schindler C, Leonard D, Fu X-Y, Aebersold R, Darnell JE, Levy DE 1992 Subunit of an alpha-interferonresponsive transcription factor is related to interferon regulatory factor and myb families of DNA-binding proteins. Mol Cell Biol 12:3315-3324

34. Delegeane AM, Ferland LH, Mellon PL 1987 Tissuespecific enhancer of the human glycoprotein hormone alpha-subunit gene: dependence on cyclic AMP-inducible elements. Mol Cell Biol 7:3994-4002

35. Chomzynski P, Sacchi N 1987 Single-step method of RNA isolation by acid guanidinium thiocyanate phenol chlorophorm extraction. Anal Biochem 162:156-159

36. Danielson PE, Forss-Petter S, Brow MA. Calavetta L, Douglas J, Milner RJ, Sutcliffe JG 1988 pIB15: a cDNA clone of the rat mRNA encoding cyclophilin. DNA 7:261267

37. Maniatis T, Fritsch EF, Sambrook J (eds) 1989 Molecular Cloning: A Laboratory Manual, ed 2. Cold Spring Harbor Laboratory, Cold Spring Harbor, NY 